\title{
Morphological and Physiological Changes of Broussonetia papyrifera Seedlings in Cadmium Contaminated Soil
}

\author{
Wan Zhang ${ }^{1}$, Yunlin Zhao ${ }^{1}$, Zhenggang Xu ${ }^{1,2, * \mathbb{D}}$, Huimin Huang ${ }^{1}$, Jiakang Zhou ${ }^{1}$ \\ and Guiyan Yang ${ }^{2}$ \\ 1 Hunan Research Center of Engineering Technology for Utilization of Environmental and Resources Plant, \\ Central South University of Forestry and Technology, Changsha 410004, China; zw@csuft.edu.cn (W.Z.); \\ zy18291290@163.com (Y.Z.); Huanghm1991@163.com (H.H.); zjk@csuft.edu.cn (J.Z.) \\ 2 College of Forestry, Northwest A \& F University, Yangling 712100, China; yangguiyan@nwsuaf.edu.cn \\ * Correspondence: xuzhenggang@nwafu.edu.cn; Tel.: +86-186-8494-5647
}

Received: 23 September 2020; Accepted: 1 December 2020; Published: 3 December 2020

check for updates

\begin{abstract}
Broussonetia papyrifera is a widely distributed economic tree species, and it is also a pioneer species in adverse environments. In order to investigate the growth and adaptation mechanism of B. papyrifera under cadmium (Cd) contaminated soil, potted experiments were used with six-month treatments to study $\mathrm{Cd}$ enrichment and the transportation, morphological and physiological characteristics of $B$. papyrifera tissues. The results showed that $\mathrm{Cd}$ mainly accumulated in the root when the Cd concentration was high $(14.71 \mathrm{mg} / \mathrm{kg})$, and the root biomass was significantly reduced by $\mathrm{Cd}$ stress although $\mathrm{Cd}$ promoted the growth of seedlings. The bioconcentration factors (BCF) increased with the increase in $\mathrm{Cd}$ concentration, and reached the maximum value of 0.21 at $14.71 \mathrm{mg} / \mathrm{kg}$. On the contrary, translocation factor (TF) decreased significantly at $8.28-14.71 \mathrm{mg} / \mathrm{kg}$ Cd concentration. $\mathrm{Cd}$ not only led to the loose arrangement of the xylem vessels of leaves, but also changed the chlorophyll content. However, B. papyrifera could synthesize organic solutes such as soluble protein, soluble sugar and proline to reduce the intracellular osmotic potential. Our study proved that B. papyrifera has good tolerance to $\mathrm{Cd}$ stress and is a pioneer tree species for soil and ecological environment restoration.
\end{abstract}

Keywords: Broussonetia papyrifera; cadmium contaminated soil; antioxidant enzyme; anatomic structure

\section{Introduction}

Due to the impact of industrialization and geochemical activities, heavy metal pollution in soil has become a serious environmental problem that limits crop production and even threatens human health through the food chain [1,2]. Cadmium (Cd) is a natural element in the earth's crust and is usually combined with other elements (such as oxygen, chlorine or sulfur) to form minerals. Over the past two centuries, a large amount of $\mathrm{Cd}$ has been released and accumulated in the soil environment $[3,4]$. The traditional method of reducing the toxicity by replacing the soil contaminated with heavy metals is highly expensive, and the placement of contaminated soil might become an urgent problem to be solved, which could even cause secondary pollution [5]. At present, phytoremediation has become a more promising method of environmental restoration based on biological extraction and filtration [6-9]. Hyperaccumulators have good application prospects in the remediation of contaminated soil, such as the first known arsenic (As) hyperaccumulation plant Pteris vittata [10-12], the manganese (Mn) hyperaccumulation plant Phytolacca acinosa [13,14], Sedum [15,16] with super enrichment ability to $\mathrm{Cd}$, etc. However, most of the hyperaccumulators are dwarf and the accumulation of heavy metals 
will also make the plants grow slowly, which brings great difficulties to their practical application. Woody plants have large biomass and a long growth cycle. Besides the developed root system, the area of stems, branches, and leaves form a larger green space. Moreover, most pollutants would not endanger people's health by food. Thus, woody plants are considered to be a candidate vegetation source for heavy metal pollution remediation.

In order to cope with different environmental conditions, plants would produce dynamic responses and positive adjustment in their biological characteristics, such as morphological structures, physiological mechanisms and even genetic characteristics [17-19]. Changes in plants' morphologies are the most intuitive response to abiotic stress. Plants could adapt to water stress by reducing stomata frequency, stomata length and reducing leaf thickness, as well as increasing the thickness of the palisade parenchyma [20]. Under the lead stress, the Artemisia Sacrorum var. Messerschmidtiana in the mineral area showed stronger tolerance than that in the non-mineral area, which was mainly reflected in the thickening of the stem epidermis, cell wall and xylem tube wall [21]. Under the condition of low Mn concentration ( $1 \mathrm{mmol} / \mathrm{L})$, the biomass, surface area and root volume of B. papyrifera were increased [22]. Of course, the physiological response would not be absent in the process of coping with environmental stress. Plants could resist the toxicity of $\mathrm{Cd}$ and $\mathrm{Mn}$ by promoting the synthesis of soluble protein and increasing the activities of antioxidant enzyme, while high concentrations of $\mathrm{Cd}$ and $\mathrm{Mn}$ led to the increase in malondialdehyde (MDA), proline and $\mathrm{H}_{2} \mathrm{O}_{2}$ content, causing membrane lipid peroxidation and severe membrane damage $[22,23]$. Studies have also shown that Cd could inhibit the photochemical reaction of plant photosynthesis and destroy the metabolism of chlorophyll, and is an effective inhibitor of photosynthesis [6,24,25].

Broussonetia papyrifera, also known as paper mulberry, is a deciduous tree or shrub. It is widely distributed around the world, providing possibilities for extensive ecological restoration [26,27]. The B. papyrifera also has high economic benefits, its bast cellulose content can be as high as $63.76 \%$ [28], which can be blended with cotton [29], and the earliest high quality bark cloth was made of B. papyrifera bast $[30,31]$. The leaves are rich in amino acids, proteins, fats and trace elements, which makes them a good source of feed. In addition, the leaves are covered with fine pubescence and can be used to monitor the air pollution in their growing areas [32]. As a medicinal resource, B. papyrifera's flowers are natural antioxidants and can treat impotence and ophthalmic diseases [33,34]. The fruit extract is not only a traditional medicine for treating cardiovascular diseases, but also contains alkaloids as a drug candidate for treating cancer [35]. Stem bark has a high content of phenolic compounds and is a potential resource for medical pharmaceuticals and anti-inflammatory drugs [36,37]. The root system of the B. papyrifera is very developed. Under natural conditions, it is mainly propagated by root sprout, and it is an environmental tree species that prevents soil erosion. Because of its fast-growing and adaptable ability, the tree is a pioneer species in desertification areas, mines, rivers, valleys, droughts and other extreme environments [38,39].

Based on the good economic potentiality and environmental effects, B. papyrifera is an important candidate plant for phytoremediation [22]. At present, the research on the adversity of B. papyrifera mostly focuses on drought and saline-alkali stresses [40-42]. There are few studies on the tolerance mechanism under heavy metal pollution. Among them, Zhao et al. [43] investigated the heavy metal enrichment of heavy metal polluted plants and found that B. papyrifera had higher enrichment ability for $\mathrm{Pb}$ and $\mathrm{Zn}$, especially the leaf part, and the $\mathrm{Cd}$ enrichment ability was also higher than in other species. The manner in which B. papyrifera responds to heavy metal stress requires a detailed analysis. In order to explore more details about the response of B. papyrifera to Cd stress, the seedling growth, leaf anatomical structure and related physiological indexes of B. papyrifera were determined under different $C d$ stress conditions. The research can not only help understand the mechanism of B. papyrifera adaptation to poor environments, but also help to establish a technical ecology restoration system based on the tree. 


\section{Results}

\subsection{Height Changes and the Characteristics of Leaf Phenotype}

Within $180 \mathrm{~d}$ of Cd stress, the height of B. papyrifera seedlings in the soil without Cd solution irrigation (non-irrigated soil) did not change significantly $(p>0.05)$ (Figure 1$)$. The initial height of all B. papyrifera seedlings averaged about $40 \mathrm{~cm}$. In order to adapt to the seasonal changes, the plant entered the wintering period and stopped growing at $90 \mathrm{~d}$. At this stage, the growth change of B. papyrifera under $5.71 \mathrm{mg} / \mathrm{kg} \mathrm{Cd}$ concentration was the largest, with an increase of $38.34 \pm 5.31 \mathrm{~cm}$. At $180 \mathrm{~d}$, the height of seedlings increased significantly at $11.49 \mathrm{mg} / \mathrm{kg}$ and $14.71 \mathrm{mg} / \mathrm{kg} \mathrm{Cd}$ concentrations, indicating that $\mathrm{Cd}$ stress can stimulate the growth of B. papyrifera seedlings. After $20 \mathrm{~d}$, the leaf phenotype of $B$. papyrifera seedlings changed (Figure S1: The photo shows the second fully expanded leaf of the seedling from top to bottom), especially at $11.49 \mathrm{mg} / \mathrm{kg}$ and $14.71 \mathrm{mg} / \mathrm{kg} \mathrm{Cd}$ concentrations. There were folds on the surface of the leaves. In addition, at a Cd concentration of $8.28 \mathrm{mg} / \mathrm{kg}$, linear spots appeared at the tip of the leaves.

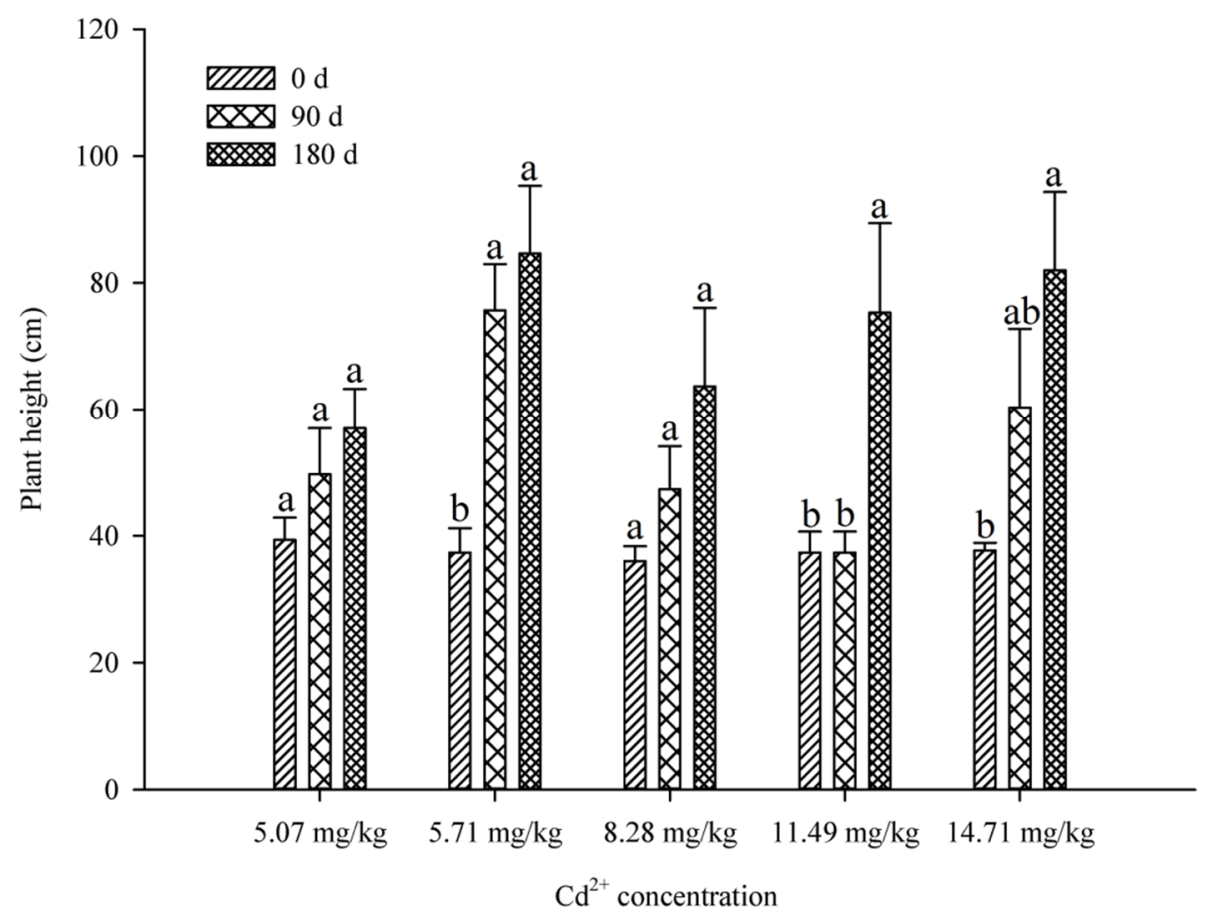

Figure 1. The height of B. papyrifera seedlings at soils of different $\mathrm{Cd}$ concentration. In this graph, $0 \mathrm{~d}$ is the height before Cd stress treatment; $90 \mathrm{~d}$ is the height of the B. papyrifera seedlings entering the stagnant growth period during winter; $180 \mathrm{~d}$ is the height of harvest. Results are expressed as mean $\pm \mathrm{SE}$ of three replicates. Different letters indicate significant differences between the same indicators $(p<0.05)$.

\subsection{Changes in Biomass and Moisture Content (MC)}

Compared with non-irrigated soil, the results showed that application of Cd solution significantly reduced the root biomass, but had no significant effect on the biomass of the stem and leaf (Table 1). The biomass of root in the $5.07 \mathrm{mg} / \mathrm{kg}, 5.71 \mathrm{mg} / \mathrm{kg}, 8.28 \mathrm{mg} / \mathrm{kg}, 11.49 \mathrm{mg} / \mathrm{kg}$ and $14.71 \mathrm{mg} / \mathrm{kg}$ experimental groups accounted for $38.11 \%, 24.27 \%, 25.12 \%, 31.85 \%$ and $29.99 \%$ of whole plant biomass, respectively. In addition, the $\mathrm{MC}$ in root and stem of the seedlings was not affected significantly $(p>0.05)$; the MC of the roots was $75-80 \%$, and the stems' MC was $60-70 \%$. 
Table 1. The dry weight (DW), fresh weight (FW) and moisture content (MC) of root, stem and leaf for the B. papyrifera seedlings at different $\mathrm{Cd}$ concentration soils. The data are presented with the mean $\pm \mathrm{SE}$ of three replicates. Different letters indicate significant differences between the same indicators $(p<0.05)$.

\begin{tabular}{cccccccc}
\hline $\begin{array}{c}\text { Cd } \\
\begin{array}{c}\text { Concentrations } \\
(\mathbf{m g} / \mathbf{k g})\end{array}\end{array}$ & Root & & & Stem & & & Leaf $^{+}$ \\
\hline & FW $(\mathrm{g})$ & $\mathrm{DW}(\mathrm{g})$ & $\mathrm{MC}(\%)$ & $\mathrm{FW}(\mathrm{g})$ & $\mathrm{DW}(\mathrm{g})$ & $\mathrm{MC}(\%)$ & $\mathrm{DW}(\mathrm{g})$ \\
\hline & $28.72 \pm$ & $6.30 \pm$ & $78.02 \pm$ & $13.65 \pm$ & $4.91 \pm$ & $63.00 \pm$ & $5.32 \pm$ \\
& $2.84 \mathrm{a}$ & $0.57 \mathrm{a}$ & $0.00 \mathrm{a}$ & $1.50 \mathrm{a}$ & $0.21 \mathrm{a}$ & $0.09 \mathrm{a}$ & $0.57 \mathrm{a}$ \\
& $16.51 \pm$ & $3.85 \pm$ & $76.70 \pm$ & $15.89 \pm$ & $6.01 \pm$ & $62.05 \pm$ & $6.00 \pm$ \\
& $0.45 \mathrm{~b}$ & $0.14 \mathrm{ab}$ & $0.01 \mathrm{a}$ & $3.47 \mathrm{a}$ & $1.29 \mathrm{a}$ & $0.02 \mathrm{a}$ & $0.80 \mathrm{a}$ \\
& $13.20 \pm$ & $3.02 \pm$ & $77.03 \pm$ & $11.39 \pm$ & $4.48 \pm$ & $60.45 \pm$ & $4.52 \pm$ \\
& $0.56 \mathrm{~b}$ & $0.22 \mathrm{~b}$ & $0.04 \mathrm{a}$ & $2.04 \mathrm{a}$ & $0.81 \mathrm{a}$ & $0.04 \mathrm{a}$ & $1.00 \mathrm{a}$ \\
& $17.56 \pm$ & $3.94 \pm$ & $77.74 \pm$ & $12.22 \pm$ & $4.15 \pm$ & $66.00 \pm$ & $4.28 \pm$ \\
& $3.37 \mathrm{~b}$ & $0.81 \mathrm{~b}$ & $0.02 \mathrm{a}$ & $0.90 \mathrm{a}$ & $0.27 \mathrm{a}$ & $0.01 \mathrm{a}$ & $0.28 \mathrm{a}$ \\
& $16.33 \pm$ & $3.53 \pm$ & $78.50 \pm$ & $11.46 \pm$ & $4.37 \pm$ & $62.14 \pm$ & $3.87 \pm$ \\
& $2.12 \mathrm{~b}$ & $0.51 \mathrm{~b}$ & $0.01 \mathrm{a}$ & $1.61 \mathrm{a}$ & $0.73 \mathrm{a}$ & $0.03 \mathrm{a}$ & $0.82 \mathrm{a}$ \\
\hline
\end{tabular}

+ Note: The determination of leaf FW and MC was omitted due to deciduous phenomena in the B. papyrifera seedlings, which occurred as a result of seasonal reasons and the long experiment period.

\subsection{Cd Content in B. papyrifera Tissues}

After $180 \mathrm{~d}$, with the increase in Cd concentration, the Cd contents in the root, stem and leaf of B. papyrifera all reached the maximum value at $14.71 \mathrm{mg} / \mathrm{kg}$ (Table 2). Under the treatment of high concentration of $\mathrm{Cd}(14.71 \mathrm{mg} / \mathrm{kg})$, the accumulation of $\mathrm{Cd}$ in B. papyrifera tissue was as follows: root $>$ leaf $>$ stem, while the accumulation ability of different tissues was leaf $>$ stem $>$ root under the treatment of lower Cd concentrations $(5.07 \mathrm{mg} / \mathrm{kg}$ and $5.71 \mathrm{mg} / \mathrm{kg}$ ). The greater the Cd concentration, the greater the $\mathrm{BCF}$ value, indicating that $\mathrm{B}$. papyrifera has a stronger ability to accumulate $\mathrm{Cd}$ at a higher concentration. With the increase in Cd concentration, the value of TF gradually decreased, and it decreased significantly at $8.28-14.71 \mathrm{mg} / \mathrm{kg}(p<0.05)$.

Table 2. Cd content in the root, stem and leaf of B. papyrifera and the accumulation and translocation of $\mathrm{Cd}$ in B. papyrifera after $180 \mathrm{~d}$ of $\mathrm{Cd}$ treatment. The data are presented with the mean $\pm \mathrm{SE}$ of three replicates. Different letters indicate significant differences between the same indicators $(p<0.05)$.

\begin{tabular}{cccccc}
\hline \multirow{2}{*}{$\begin{array}{c}\text { Cd } \\
\text { Concentrations } \\
(\mathbf{m g} / \mathbf{k g})\end{array}$} & \multicolumn{2}{c}{ Cd Concentration (mg/kg DW) } & \multirow{2}{*}{ BCF } & TF \\
\cline { 2 - 5 } & Root & Stem & Leaf & & \\
\hline 5.07 & $0.15 \pm 0.04 \mathrm{~b}$ & $0.60 \pm 0.10 \mathrm{bc}$ & $1.20 \pm 0.10 \mathrm{c}$ & $0.12 \pm 0.01 \mathrm{~b}$ & $6.87 \pm 1.74 \mathrm{a}$ \\
5.71 & $0.26 \pm 0.10 \mathrm{~b}$ & $0.41 \pm 0.04 \mathrm{c}$ & $1.43 \pm 0.15 \mathrm{bc}$ & $0.14 \pm 0.00 \mathrm{~b}$ & $4.81 \pm 1.88 \mathrm{a}$ \\
8.28 & $1.58 \pm 0.28 \mathrm{ab}$ & $0.68 \pm 0.07 \mathrm{~b}$ & $1.65 \pm 0.14 \mathrm{~b}$ & $0.18 \pm 0.02 \mathrm{ab}$ & $0.78 \pm 0.14 \mathrm{~b}$ \\
11.49 & $1.43 \pm 0.04 \mathrm{ab}$ & $1.31 \pm 0.04 \mathrm{a}$ & $1.46 \pm 0.07 \mathrm{bc}$ & $0.19 \pm 0.01 \mathrm{a}$ & $0.97 \pm 0.04 \mathrm{~b}$ \\
14.71 & $4.28 \pm 1.69 \mathrm{a}$ & $1.43 \pm 0.04 \mathrm{a}$ & $2.10 \pm 0.04 \mathrm{a}$ & $0.21 \pm 0.02 \mathrm{a}$ & $0.56 \pm 0.21 \mathrm{~b}$ \\
\hline
\end{tabular}

\subsection{Anatomic Structure of Leaves}

After two months of Cd stress, the anatomical structures of the B. papyrifera leaves treated with different $\mathrm{Cd}$ concentrations were observed (Figure 2). The leaves of $B$. papyrifera have relatively complete epidermis (including cuticle, upper epidermis and lower epidermis) in all groups. The palisade tissue was more developed, arranged neatly and tightly, and some dense dark spots were visible inside, containing more chloroplasts. Developed palisade tissue can greatly improve the photosynthesis efficiency of B. papyrifera and promote its rapid growth. At the same time, the sponge tissue distribution was relatively uneven, the arrangement was loose, and the chloroplast was less affected by $\mathrm{Cd}$. Compared with low Cd concentration $(5.07 \mathrm{mg} / \mathrm{kg})$, the tightness of the palisade tissue was loose under the $\mathrm{Cd}$ treatments of $5.71 \mathrm{mg} / \mathrm{kg}, 8.28 \mathrm{mg} / \mathrm{kg}$ and $11.49 \mathrm{mg} / \mathrm{kg}$, and the arrangement was disordered, 
while it was alleviated at $14.71 \mathrm{mg} / \mathrm{kg}$. The xylem vessels in $5.07 \mathrm{mg} / \mathrm{kg}$ were arranged closely. With the concentration increasing, the vessels were arranged loosely, which directly affects the absorption of inorganic salt ions and water in B. papyrifera. The phloem fiber was tough and has strong flexing resistance. It is mainly responsible for the transport of organic matter (sugar, protein, etc.) and some mineral element ions. The phloem of the B. papyrifera leaves after $\mathrm{Cd}$ stress was faintly visible, but its thickness decreased with the increase in stress concentration, which was most obvious at $8.28 \mathrm{mg} / \mathrm{kg}$.
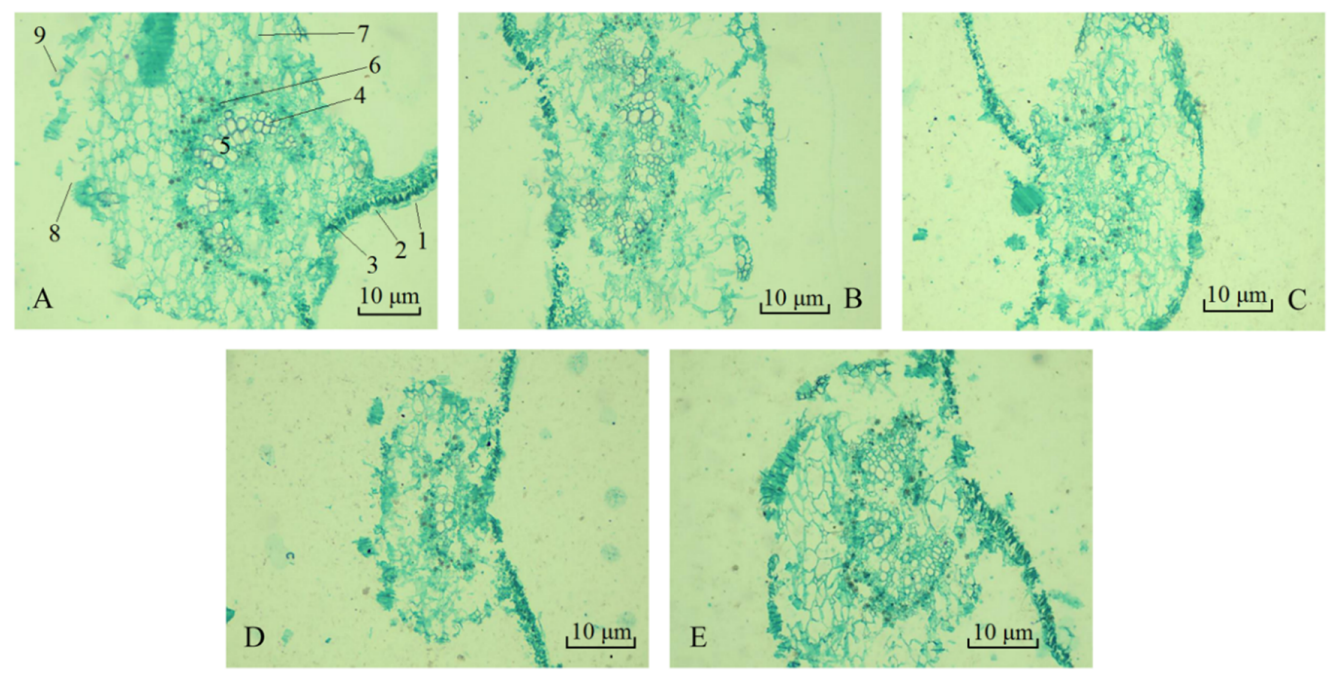

Figure 2. The anatomical structure of the transverse section of the B. papyrifera leaves. (A-E) (100×) correspond to $5.07 \mathrm{mg} / \mathrm{kg}, 5.71 \mathrm{mg} / \mathrm{kg}, 8.28 \mathrm{mg} / \mathrm{kg}, 11.49 \mathrm{mg} / \mathrm{kg}$ and $14.71 \mathrm{mg} / \mathrm{kg}$ of Cd treated B. papyrifera leaves, respectively. The numbers in (A) indicate: 1-cuticle, 2-upper epidermis, 3-palisade tissue, 4-xylem, 5-vessel, 6-phloem, 7—sponge tissue, 8-stomata, 9-lower epidermis.

\subsection{Physiological Characteristics of B. Papyrifera Seedlings}

\subsubsection{Changes in Soluble Protein Content, Soluble Sugar Content and Proline Content}

The soluble protein content, soluble sugar content and proline content of B. papyrifera leaves have changed over time in all groups (Figure 3). Two-way analyses of variance showed that the soluble protein content of $B$. papyrifera seedlings was hardly affected by the $C d$ concentration variable, while the stress time could significantly affect the soluble protein content $(p<0.001)$ (Figure 3A). At $12 \mathrm{~h}$, the soluble protein content decreased significantly under $14.71 \mathrm{mg} / \mathrm{kg} \mathrm{Cd}$ concentration $(p<0.05)$. As the stress time prolonged, at $10 \mathrm{~d}$ and $20 \mathrm{~d}$, the soluble protein content increased with the increase in the $\mathrm{Cd}$ concentration. On the other hand, at $30 \mathrm{~d}$, the soluble protein content in all treatment groups increased significantly $(p<0.05)$ (Figure $3 \mathrm{~A})$, while it first decreased and then increased at the low $\mathrm{Cd}$ concentration $(5.07 \mathrm{mg} / \mathrm{kg})$.

Soluble sugar, as a carbohydrate, is the main raw material and storage material for plant metabolism. For the low Cd concentration $(5.07 \mathrm{mg} / \mathrm{kg}$ and $5.71 \mathrm{mg} / \mathrm{kg})$, the soluble sugar content had no significant difference except for $20 \mathrm{~d}(p<0.05$, Figure 3B). With the increase in Cd concentration, the soluble sugar content decreased at $12 \mathrm{~h}$, while at $10 \mathrm{~d}, 20 \mathrm{~d}$ and $30 \mathrm{~d}$, the soluble sugar content increased first and then decreased. At $10 \mathrm{~d}$ and $20 \mathrm{~d}$, both reached the maximum under $8.28 \mathrm{mg} / \mathrm{kg} \mathrm{Cd}$ concentration, but there was no significant difference between the $14.71 \mathrm{mg} / \mathrm{kg}$ and $5.07 \mathrm{mg} / \mathrm{kg} \mathrm{Cd}$ treatment groups. In the same $\mathrm{Cd}$ treatment group, the soluble sugar content increased significantly after $20 \mathrm{~d}$ (Figure 3B). In the non-irrigated soil, affected by the $\mathrm{Cd}$ content in the soil, the soluble sugar content decreased significantly at $10 \mathrm{~d}(p<0.05)$, but it was not significantly different after $20 \mathrm{~d}$. 


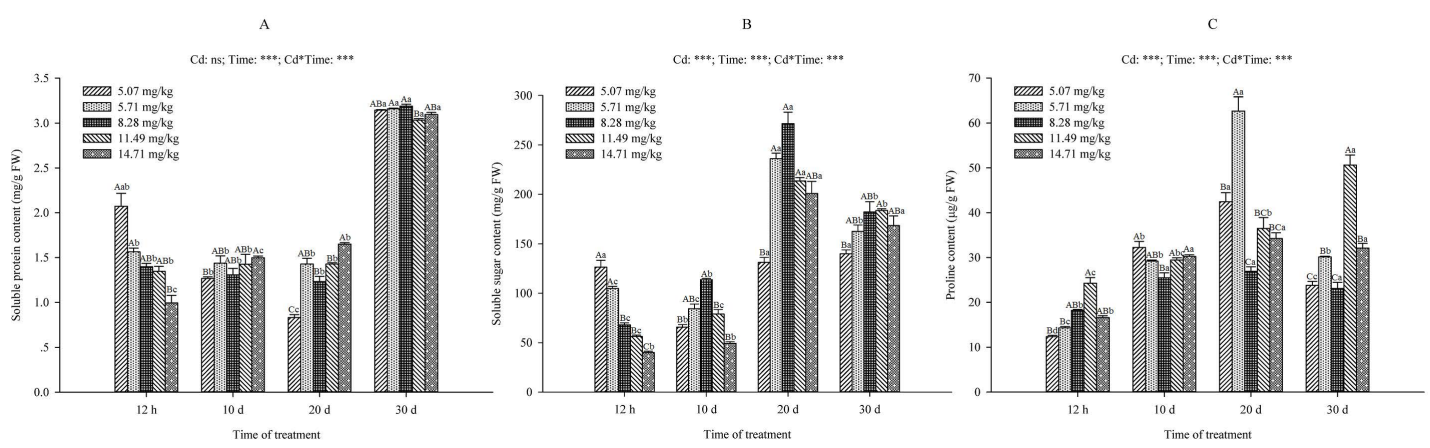

Figure 3. Effects of different Cd concentrations on the soluble protein content (mg/g FW) (A), soluble sugar content (mg/g FW) (B) and proline content ( $\mu \mathrm{g} / \mathrm{g}$ FW) (C) of B. papyrifera seedlings. Results are expressed as mean $\pm \mathrm{SE}$ of three replicates. Different uppercase letters indicate significant differences $(p<0.05)$ between Cd content, and different lowercase letters indicate significant differences $(p<0.05)$ between treatment times. Cd, Cd content effect; Time, time effect; $\mathrm{Cd}^{*}$ Time, the interactive effect of $\mathrm{Cd}$ content and time. ns, not significant; ${ }^{* * *}$ represents $p \leq 0.001$.

The change of proline content in B. papyrifera leaves showed that in a short period of time $(12 \mathrm{~h})$, the proline content increased first and then decreased with the increase in $\mathrm{Cd}$ concentration in soil. However, there was no significant difference between low Cd concentrations $(5.07 \mathrm{mg} / \mathrm{kg}$ and $5.71 \mathrm{mg} / \mathrm{kg})(p>0.05)$ (Figure 3C). The data ranges from $12.34 \pm 0.31 \mu \mathrm{g} / \mathrm{g}$ FW to $24.25 \pm 1.27 \mu \mathrm{g} / \mathrm{g} \mathrm{FW}$. With the extension of time, even if the concentration was very low, it would be significantly different from the non-irrigated soil. At $20 \mathrm{~d}$, the content of proline in the $5.71 \mathrm{mg} / \mathrm{kg}$ Cd concentration reached $62.69 \pm 3.16 \mu \mathrm{g} / \mathrm{g}$ FW, which was $42.42 \pm 2.04 \mu \mathrm{g} / \mathrm{g}$ FW higher than the $5.07 \mathrm{mg} / \mathrm{kg}$ Cd concentration $(p<0.05)$. At $30 \mathrm{~d}$, the content of proline in the $5.71 \mathrm{mg} / \mathrm{kg} \mathrm{Cd}$ concentration was also significantly higher than that in the $5.07 \mathrm{mg} / \mathrm{kg} \mathrm{Cd}$ concentration $(p<0.05)$. In the different groups, the proline content increased with the extension of time, and the change was most significant at $10 \mathrm{~d}$ (Figure 3C).

\subsubsection{Changes in MDA Content and Antioxidant Enzyme Activity}

In all groups, MDA content, SOD, POD and CAT activities increased with prolonged stress time (Figure 4). In a short period of time (12 h), the content of MDA in B. papyrifera leaves was significantly higher in high Cd concentrations $(11.49 \mathrm{mg} / \mathrm{kg}$ and $14.71 \mathrm{mg} / \mathrm{kg}$ ) than in low Cd concentrations $(5.07 \mathrm{mg} / \mathrm{kg}$ and $5.71 \mathrm{mg} / \mathrm{kg}$ ) (Figure $4 \mathrm{~A})$. With the extension of stress time, there was no significant difference between low $\mathrm{Cd}$ concentration and high $\mathrm{Cd}$ concentration. The results showed that high $\mathrm{Cd}$ concentration has a greater impact on B. papyrifera seedlings in a short time and more ROS accumulated in B. papyrifera. Increased antioxidant enzyme activity could reduce oxidative damage caused by active oxygen accumulation. At $12 \mathrm{~h}$, the activities of SOD, POD and CAT increased with the increasing of the $\mathrm{Cd}$ concentration, and the difference was significant from $5.07 \mathrm{mg} / \mathrm{kg} \mathrm{Cd}$ concentration $(p<0.05)$ (Figure 4B-D). Among them, at $14.71 \mathrm{mg} / \mathrm{kg}$ Cd concentration, the activities of SOD, POD and CAT were $729.71 \pm 4.13 \mathrm{U} / \mathrm{mg}$ prot, $329.40 \pm 5.49 \mathrm{U} / \mathrm{mg}$ prot and $110.33 \pm 6.24 \mathrm{U} / \mathrm{mg}$ prot, respectively, which were more than twice as much as those at $5.07 \mathrm{mg} / \mathrm{kg}$ Cd concentration with $298.24 \pm 7.47 \mathrm{U} / \mathrm{mg}$ prot, $153.77 \pm 3.10 \mathrm{U} / \mathrm{mg}$ prot and $36.75 \pm 1.64 \mathrm{U} / \mathrm{mg}$ prot, respectively. With the extension of the stress time, the activities of the three antioxidant enzymes in the high Cd concentration decreased. At $10 \mathrm{~d}$ and $20 \mathrm{~d}$, the $14.71 \mathrm{mg} / \mathrm{kg} \mathrm{Cd}$ treatment groups were significantly lower than non-irrigated soil, indicating that long-term high $\mathrm{Cd}$ stress caused greater oxidative damage to B. papyrifera seedlings. It could also be seen from the change of time that the accumulation of $\mathrm{Cd}$ led to the increase in MDA content and the activation of antioxidant enzyme activities in B. papyrifera seedlings (Figure 4A-D). 

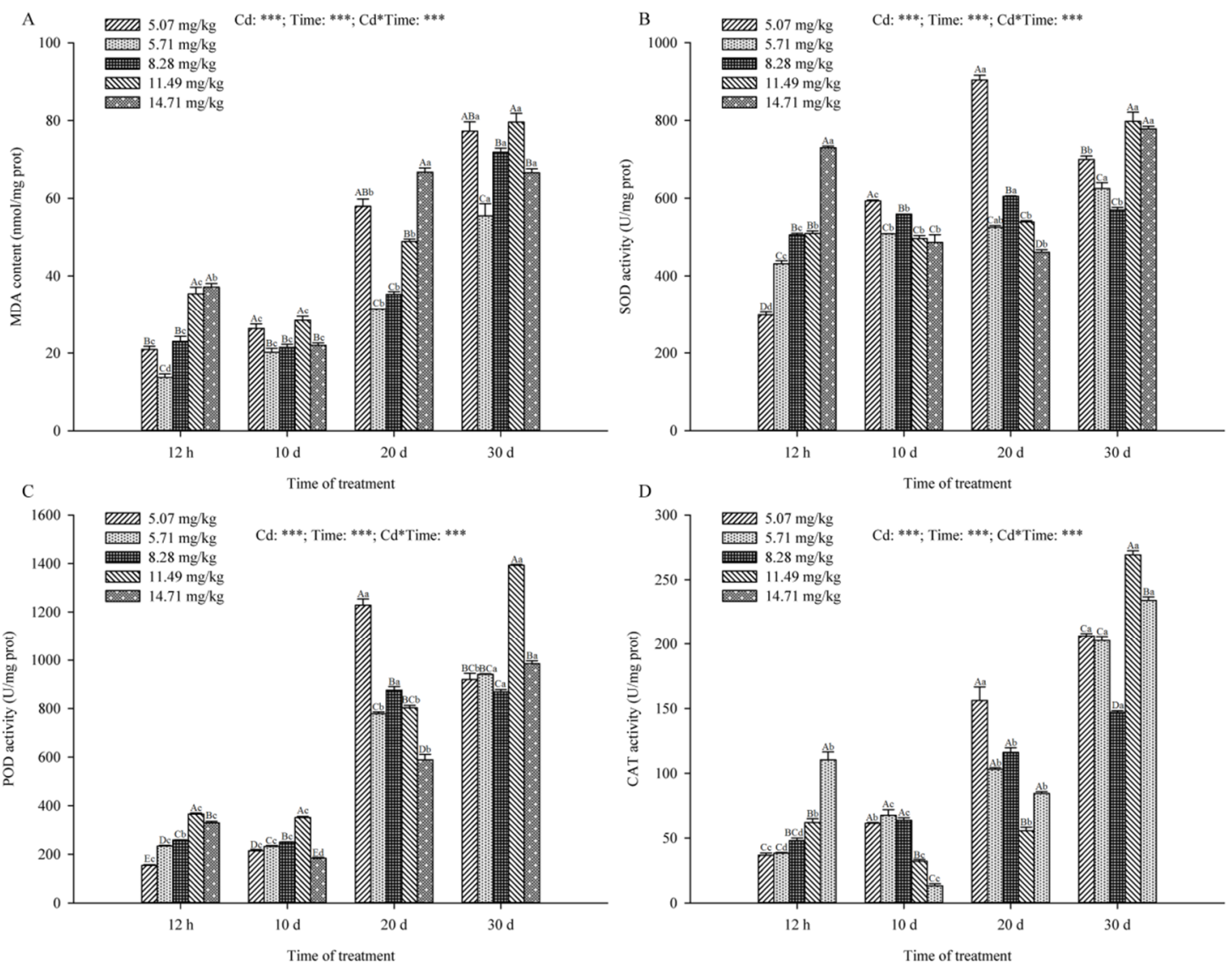

Figure 4. The effects of different $\mathrm{Cd}$ treatment concentrations on the MDA content (nmol/mg prot) (A), SOD activity (U/mg prot) (B), POD activity (U/mg prot) (C) and CAT activity (U/mg prot) (D) of B. papyrifera seedlings. Results are expressed as mean \pm SE of three replicates. Different uppercase letters indicate significant differences $(p<0.05)$ between $\mathrm{Cd}$ content, and different lowercase letters indicate significant differences $(p<0.05)$ between treatment times. $\mathrm{Cd}, \mathrm{Cd}$ content effect; Time, time effect; $C d^{*}$ Time, the interactive effect of $\mathrm{Cd}$ content and time. ${ }^{* * *}$ represents $p \leq 0.001$.

\subsubsection{Changes in Chlorophyll Content}

The chlorophyll content in plants is closely related to photosynthesis and nutritional status, and is an important indicator reflecting the growth of plants. The chlorophyll content (chlorophyll $a$, chlorophyll $b$ and total chlorophyll) of the B. papyrifera leaves showed an overall upward trend with the extension of $C d$ stress time (Figure 5). At $12 \mathrm{~h}$, the chlorophyll content under $5.71 \mathrm{mg} / \mathrm{kg}$ and $8.28 \mathrm{mg} / \mathrm{kg}$ $\mathrm{Cd}$ concentrations was significantly lower than that of non-irrigated soil, while the difference between high Cd concentrations $(11.49 \mathrm{mg} / \mathrm{kg}$ and $14.71 \mathrm{mg} / \mathrm{kg})$ and non-irrigated soil was not significant $(p>0.05)$. As time extended, the difference between $5.07 \mathrm{mg} / \mathrm{kg}, 5.71 \mathrm{mg} / \mathrm{kg}$ and $8.28 \mathrm{mg} / \mathrm{kg}$ decreased. On the whole, the content of chlorophyll in non-irrigated soil was higher than that of other $\mathrm{Cd}$ treatment groups. Furthermore, at $30 \mathrm{~d}$, there was a significant difference $(p<0.05)$; the lowest chlorophyll content was at $11.49 \mathrm{mg} / \mathrm{kg}$ Cd concentration. The comparison of chlorophyll $a$ and chlorophyll $b$ content found that chlorophyll $b$ content was higher than chlorophyll $a$ under the same treatment conditions. The results indicated that $\mathrm{Cd}$ had an inhibitory effect on chlorophyll synthesis in the B. papyrifera seedlings. 


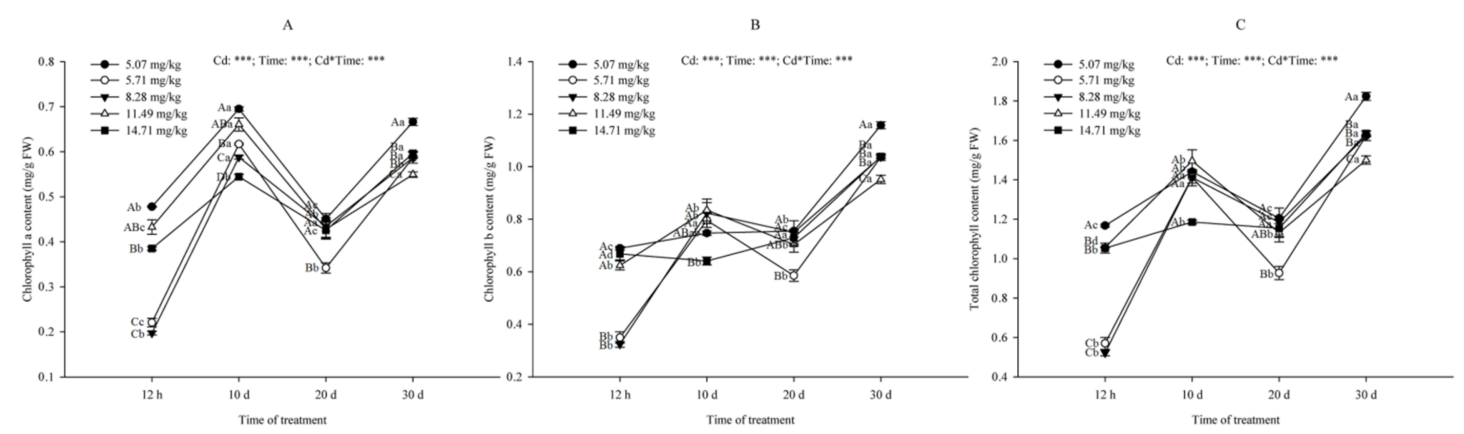

Figure 5. Effects of different $C d$ treatment concentrations on chlorophyll $a$ content $(\mathrm{mg} / \mathrm{g} \mathrm{FW})$ (A), chlorophyll $b$ content $(\mathrm{mg} / \mathrm{g} \mathrm{FW})($ B) and total chlorophyll content (mg/g FW) (C) of B. papyrifera seedlings. Results are expressed as mean \pm SE of three replicates. Different uppercase letters indicate significant differences $(p<0.05)$ between Cd content, and different lowercase letters indicate significant differences $(p<0.05)$ between treatment times. $\mathrm{Cd}$, Cd content effect; Time, time effect; Cd*Time, the interactive effect of $\mathrm{Cd}$ content and time. ${ }^{* * *}$ represents $p \leq 0.001$.

\section{Discussion}

Elevated concentrations of essential and non-essential heavy metals in plants can inhibit plant growth and cause toxic symptoms. However, plants have a range of potential mechanisms at the cellular level that may be involved in detoxification, and thus resistance to heavy metal stress. For example, organic solutes such as soluble protein, soluble sugar, proline and organic acid are synthesized in the cell to reduce the intracellular osmotic potential and maintain the normal supply of water. The efflux of heavy metals reduces the absorption of heavy metals on the plasma membrane. In addition, plants could increase their enzyme activity to drive off reactive oxygen species (ROS), thereby repairing stress-damaged proteins [44,45]. Under normal circumstances, plant intake of large amounts of heavy metals may stimulate the formation of ROS in the body. These ROS, especially $\mathrm{H}_{2} \mathrm{O}_{2}$, are the most influential signal transduction factors in plant growth $[46,47]$, which can cause oxidative stress reaction with proteins, lipids and other substances in plants [48]. In this process, the cell membrane permeability is enhanced, there is a lack of necessary metal in metalloprotein complexes, and toxic heavy metals are eventually replaced [49], while the removal of ROS is an important measure to reduce the damage to biological macromolecules such as proteins, sugars and nucleic acids. The balance between antioxidants and free radicals can play a useful biological function without causing too much damage [50].

Plant biomass has been widely used to evaluate the $\mathrm{Cd}$ tolerance of plants. Studies have shown that the plant biomass decreases significantly when the Cd content in soil is high [51,52]. In this study, $\mathrm{Cd}$ had a greater impact on the biomass of B. papyrifera root. When the $\mathrm{Cd}$ concentration reached $8.28 \mathrm{mg} / \mathrm{kg}$, the biomass of the root decreased significantly compared with non-irrigated soil $(5.07 \mathrm{mg} / \mathrm{kg})$ $(p<0.05)$, while the biomass of the leaf and stem was not affected by $\mathrm{Cd}$. This shows that $\mathrm{Cd}$ seriously affects the growth of roots. At the same time, under the high Cd concentration $(14.71 \mathrm{mg} / \mathrm{kg})$, the Cd content in the root of $B$. papyrifera was the highest, which was about three times and twice that in the stem and leaf, respectively. The research on $\mathrm{Cd}$ content showed that at low $\mathrm{Cd}$ concentrations $(5.07 \mathrm{mg} / \mathrm{kg}$ and $5.71 \mathrm{mg} / \mathrm{kg}), \mathrm{Cd}$ was mostly accumulated in the leaf, while it was mainly accumulated in the root at high $\mathrm{Cd}$ concentration. This is different from the accumulation of $\mathrm{Mn}$ in B. papyrifera [22]. The BCF of B. papyrifera increased significantly at the Cd concentrations of $11.49-14.71 \mathrm{mg} / \mathrm{kg}$, while TF decreased significantly at $8.28-14.71 \mathrm{mg} / \mathrm{kg}$. The above results indicated that B. papyrifera has a strong absorption capacity for heavy metals in the soil under high $\mathrm{Cd}$ concentration, and the metals mainly accumulate in the underground part; this may occur because the root cell wall of B. papyrifera selectively absorbs and fixes $C d$ in the soil, so most of the $C d$ was trapped in the root [23,53]. In addition, most studies have also shown that heavy metals can reduce the MC of plants [54,55]. In our research, there was no significant difference in the MC of each part of B. papyrifera, indicating that the tissues of B. papyrifera have stronger water holding capacity. 
As an important osmotic adjustment substance and nutrient, soluble protein can increase the water retention capacity of the cells and protect the biofilm. In our research, the soluble protein content of B. papyrifera leaves decreased with the increase in Cd concentration at $12 \mathrm{~h}$. At this time, the increase in MDA content indicated that it may be caused by the accumulation of ROS in the body $[54,56,57]$. MDA content is an important indicator reflecting the strength of lipid peroxidation, which indirectly reflects the severity of cells attacked by ROS [58]. With the prolongation of time, the soluble protein content increased significantly in order to adapt to the adversity. The B. papyrifera maintained the normal metabolism of the cells and increased the stress resistance by increasing the number of functional proteins [59]. From the results, we can see that in the non-irrigated soil (Figure 3), the soluble protein content first decreased and then increased with the extension of $\mathrm{Cd}$ treatment time. According to the test results of the $\mathrm{Cd}$ content in the soil, this may be related to the $\mathrm{Cd}$ contained in the soil itself. Moreover, the soluble protein content of B. papyrifera seedlings in the $\mathrm{Cd}$ treatment groups also increased significantly at $30 \mathrm{~d}$, indicating that the $B$. papyrifera seedlings could detoxify by increasing the protein content after adapting to the $\mathrm{Cd}$ stress environment.

It can be seen from the change of soluble sugar content that with the increase in $\mathrm{Cd}$ concentration and the extension of stress time, B. papyrifera adjusted the osmotic pressure to adapt to environmental pressure by increasing the soluble sugar content. Soluble sugars in plants, such as sucrose, glucose and fructose, can offer protection from freezing damage caused by low temperature stress and can induce an increase in enzyme activity to drive out higher $\mathrm{H}_{2} \mathrm{O}_{2}$; for this reason, they are known as good membrane protectants [60-62]. Moreover, transcriptome analysis confirmed that gene expression involved in the regulation of sugar signal transduction is associated with oxidative stress [63]. This is why the B. papyrifera has an increase in soluble sugar at high Cd concentration.

Under stress conditions, proline accumulated in plants not only acts as an osmotic regulator in plant cytoplasm, but also plays an important role in stabilizing the structure of biological macromolecules and regulating the redox potential of cells $[64,65]$. Our research found that the proline content in all the experimental groups was in an increasing trend due to the influence of the $\mathrm{Cd}$ content in soil itself and the application of $\mathrm{Cd}$ solution. Studies have shown that heavy metals such as $\mathrm{Cd}, \mathrm{Cu}$ and $\mathrm{Zn}$ can induce the production of proline in plants [66-68]. Proline plays a protective role in heavy metal toxicity by inhibiting lipid peroxidation [67]. This was related to the water balance of plant leaves [68]. Chen et al. [69] found that abscisic acid (ABA) induced an increase in proline content in rice under $\mathrm{Cu}$ stress, and was related to the increase in amino acids. It was subsequently confirmed that amino acids and phytochelatins played a role in metal binding, and participated in the antioxidant process, promoting the increase in proline content [70]. Whether the increase in proline content in B. papyrifera is related to $\mathrm{Cd}$ induction and the regulatory mechanism remains to be confirmed.

The determination of MDA content is often combined with the determination of the activity of antioxidant enzymes. SOD, POD and CAT are key enzymes in the antioxidant system [71,72]. Under $5.71 \mathrm{mg} / \mathrm{kg}$ Cd concentration, the content of MDA in B. papyrifera decreased, indicating that B. papyrifera could adapt to low Cd stress. High Cd concentrations $(11.49 \mathrm{mg} / \mathrm{kg}$ and $14.71 \mathrm{mg} / \mathrm{kg}$ ) could accumulate ROS in B. papyrifera, leading to an increase in MDA content. Our study found that SOD, POD and CAT played a role in scavenging ROS, but SOD and POD activities were significantly higher than CAT. This phenomenon has been reported previously $[22,23,58]$, and it was indicated that SOD and POD played a major defensive role in preventing oxidative damage under $\mathrm{Cd}$ stress. CAT can participate in the catalysis of $\mathrm{H}_{2} \mathrm{O}_{2}$ decomposition and reduce $\mathrm{H}_{2} \mathrm{O}_{2}$ content under stress [73]. The MDA content also showed a significant increasing trend in the non-irrigated soil as time progressed, indicating that the B. papyrifera suffered oxidative damage. At the same time, the activity of antioxidant enzymes increased, which protects cells from Cd poisoning by removing ROS.

$\mathrm{Cd}$ can inhibit the activity of chlorophyll biosynthetic enzymes, which in turn affects the function of chloroplasts [74]. This is consistent with our results, that is, the chlorophyll content under other Cd concentrations was lower than that of the non-irrigated soil. $\mathrm{Cd}$ has an effect on the photosynthetic system of $B$. papyrifera seedlings by inhibiting the activity of chlorophyll biosynthetic enzymes. In a short 
period, the effect of low Cd concentrations $(5.71 \mathrm{mg} / \mathrm{kg}$ and $8.28 \mathrm{mg} / \mathrm{kg}$ ) on chlorophyll content was greater than that of high $\mathrm{Cd}$ concentrations, which corresponds to the chloroplast content of palisade tissue in anatomic structure of leaves. With the extension of time, the adaptability of B. papyrifera to the stress environment increased, so the chlorophyll content increased rapidly at low $\mathrm{Cd}$ concentrations. Studies have shown that when plants were exposed to lower $\mathrm{Cd}$ concentrations, their chlorophyll content was higher than that of the control $[54,75]$. We believe that low $\mathrm{Cd}$ concentration could inhibit chlorophyll synthesis in B. papyrifera leaves. In addition, we found that $\mathrm{Cd}$ changed the content of chlorophyll type in B. papyrifera leaves. As heliophytes, the ratio of chlorophyll $a / b$ should be larger, namely chlorophyll $a>$ chlorophyll $b$ [76]; the results of this study proved that the content of chlorophyll $b$ was higher than chlorophyll $a$, which is also contrary to the chlorophyll synthesis of B. papyrifera under Mn stress [22]. Hence, the changes in chlorophyll $a / b$ may be due to the special role of Cd in B. papyrifera chlorophyll synthesis.

Cadmium is toxic to plants even at very low concentrations [77]. In pot experiments, the toxic effects of $\mathrm{Cd}$ are more complicated, because $\mathrm{Cd}$ and other elements have interacted [78]. The background value of the soil in our experiment was much higher than in other studies [79,80], and the Cd content of the non-irrigated soil group has exceeded the threshold requirement for growing crops $[81,82]$. The above defects are due to the purchase of nutrient soil that does not meet the expectations of the experiment through a commercial company. The lack of a blank control prevented us from exploring the response mechanism of B. papyrifera to Cd stress. We could, however, still explore some details about morphological and physiological changes of B. papyrifera seedlings in $\mathrm{Cd}$ contaminated soil and confirm that B. papyrifera has good resistance to Cd stress. Optimistically, there are some details in the experiment that effectively slowed down the influence of the background value. First, before the stress experiment started, the B. papyrifera seedlings were adapted to the nutrient soil for two months and the influence of the background $C d$ could have been almost negligible. Secondly, as a woody plant, B. papyrifera is much more resistant to $\mathrm{Cd}$ concentration than herbs. This is also the source of our motivation to look for woody restoration plants and explore their mechanisms. On the whole, the research still showes that $B$. papyrifera reveals good $\mathrm{Cd}$ tolerance and has potential of its use as a phytoremediation.

\section{Materials and Methods}

\subsection{Source of Seedlings and $\mathrm{Cd}$ Treatment}

The plant material was an annual B. papyrifera cutting seedling, which was provided by Hunan Yuanyufeng Agricultural Co., Ltd. (Chenzhou, China). The B. papyrifera seedlings were planted in plastic pots with an outer diameter of $21 \mathrm{~cm}$ and a height of $12 \mathrm{~cm}$, with $700 \mathrm{~g}$ soil not administered with a $\mathrm{Cd}$ solution (non-irrigated soil). The pot was kept in the greenhouse at $27{ }^{\circ} \mathrm{C}$ with a $14 \mathrm{~h}$ photoperiod and $50-60 \%$ of relative air humidity. In order to prevent the loss of Cd solution, a tray was padded on the bottom of the pot. After two months of adaptive training, 15 pots of seedlings with the same growth and health status were selected for $\mathrm{Cd}$ stress treatment. The average height of B. papyrifera seedlings was about $40 \mathrm{~cm}(p>0.05)$.

During the $\mathrm{Cd}$ stress treatment, $400 \mathrm{~mL} \mathrm{CdCl}{ }_{2} \bullet 2^{1 / 2} \mathrm{H}_{2} \mathrm{O}$ solutions with $\mathrm{Cd}$ concentrations of 10,50 , 100 and $150 \mu \mathrm{mol} / \mathrm{L}$ were uniformly injected into the soil of each pot. Non-irrigated soil was watered with the same volume of deionised water but without added $\mathrm{Cd}$. Then, the plants were subjected to five levels of soil contamination corresponding to $5.07,5.71,8.28,11.49$ and $14.71 \mathrm{mg} \mathrm{Cd} / \mathrm{kg}$ soil, of which the $5.07 \mathrm{mg} / \mathrm{kg} \mathrm{Cd}$ was detected in the non-irrigated soil. Each treatment concentration was set to three replicates. All treated B. papyrifera seedlings were carried out in the greenhouse, and were maintained by regularly pouring an equal amount of deionized water into the trays. After $180 \mathrm{~d}$ treatment, the trees were harvested. 


\subsection{Determination of Growth Indicator and Cd Accumulation}

The height of each experimental plant treated with different $\mathrm{Cd}$ concentrations was measured at $0 \mathrm{~d}, 90 \mathrm{~d}$ and $180 \mathrm{~d}$, respectively. After $180 \mathrm{~d}$ of Cd stress treatment, the whole plants were harvested and washed with deionized water, then were divided into roots, stems and leaves. The fresh weight (FW) of roots and stems was measured. Then, they were dried at $105^{\circ} \mathrm{C}$ for $1 \mathrm{~h}$, and at $65^{\circ} \mathrm{C}$ to constant weight and measured dry weight (DW). The moisture content (MC) of individual plant roots and stems was calculated by: $\mathrm{MC}(\%)=(\mathrm{FW}-\mathrm{DW}) / \mathrm{FW} * 100$. The proportion of root biomass in the whole plant was based on the following formula: DWroot/(DWroot + DWstem + DWleaf)*100\%.

The dried plant tissues were ground into powder by a pulverizer (Yongkang Boou Hardware Products Co., Ltd., Yongkang, China, Dongyi: 200 T). Quantities of $0.5000 \mathrm{~g}$ of the pulverized plant samples were accurately weighed and placed into $100 \mathrm{~mL}$ erlenmeyer flasks; $5 \mathrm{~mL}$ of $\mathrm{HNO}_{3}$ was added, and the bent-neck funnel was covered, shaken well, and left to stand overnight. The next day, they were placed on an electric hot plate and heated in a fume hood at $160{ }^{\circ} \mathrm{C}$ for $1 \mathrm{~h}, 170{ }^{\circ} \mathrm{C}$ for $1 \mathrm{~h}$, $180{ }^{\circ} \mathrm{C}$ for $1 \mathrm{~h}$, and $190{ }^{\circ} \mathrm{C}$ for $30 \mathrm{~min}$ until the brown gas was almost exhausted. The erlenmeyer flasks were taken off and cooled, $1.5 \mathrm{~mL} \mathrm{HClO}_{4}$ was added, and then the temperature on the electric heating plate was again raised to $200{ }^{\circ} \mathrm{C}$ and heated for $1-2 \mathrm{~h}$ to produce thick white smoke. At this time, most of the $\mathrm{HClO}_{4}$ was volatilized. When the solution in the erlenmeyer flasks was colorless and transparent, and the plant residue was white, the erlenmeyer flasks were taken off and cooled.

In addition, the soils were air-dried naturally, crushed in a mortar, and passed through a 100 mesh nylon sieve. Quantities of $0.2000 \mathrm{~g}$ of the soil samples were accurately weighed and placed into a $100 \mathrm{~mL}$ polytetrafluoroethylene (PTFE) crucible. The fume hood was turned on, and $10 \mathrm{~mL} \mathrm{of} \mathrm{HCl}$ was added to the PTFE crucible. It was shaken gently, placed on a hot plate, and heated at $120{ }^{\circ} \mathrm{C}$ for about $1 \mathrm{~h}$. When the solution was fast-drying $(3 \mathrm{~mL})$, it was removed and cooled. Then, $5 \mathrm{~mL} \mathrm{HNO}_{3}$, $5 \mathrm{~mL} \mathrm{HF}$ and $3 \mathrm{~mL} \mathrm{HClO}_{4}$ were added, and the solution was covered and heated at $185^{\circ} \mathrm{C}$ for about $2 \mathrm{~h}$; the lid was opened to drive off the white smoke, and when about $3 \mathrm{~mL}$ remained, the PTFE crucible was removed for cooling to occur.

The plant samples and soil samples treated above were filtered with ultrapure water in $25 \mathrm{~mL}$ volumetric flasks, and the Cd content in the samples was measured with a flame atomic absorption spectrophotometer.

The calculation formula of $\mathrm{Cd}$ content in plant tissue was as follows:

$$
\text { Cd content }(\mathrm{mg} / \mathrm{kg} \mathrm{DW})=\text { detected Cd concentration } * 25 * 10^{-3} / 0.5 * 10^{-3} \text {. }
$$

The calculation formula of Cd content in soil was as follows:

$$
\text { Cd content }(\mathrm{mg} / \mathrm{kg} \mathrm{DW})=\text { detected Cd concentration } * 25 * 10^{-3} / 0.2 * 10^{-3} \text {. }
$$

The larger the bioconcentration factor $(\mathrm{BCF})$, the stronger the ability of plants to accumulate Cd; the larger the translocation factor $(\mathrm{TF})$, the stronger the ability of plants to transport $\mathrm{Cd}$ from the roots to the aboveground part. $\mathrm{BCF}=$ the content of $\mathrm{Cd}$ in plants/the content of $\mathrm{Cd}$ in soil; $\mathrm{TF}=\mathrm{Cd}$ content in the aboveground part (leaf and stem) of the plant/Cd content in the underground part (root) of the plant.

\subsection{Determination of Physiological Characteristics}

Fresh leaves were collected after B. papyrifera was treated for 12 h, $10 \mathrm{~d}, 20 \mathrm{~d}$ and $30 \mathrm{~d}$, respectively. Then, under ice water bath conditions, liquid nitrogen was added and the leaf was rapidly ground into $10 \%$ tissue homogenate. After centrifugation at $4500 \mathrm{rpm}$ for $10 \mathrm{~min}$, the supernatant was taken for determination of soluble protein content, soluble sugar content, proline content, MDA content, superoxide dismutase (SOD) activity, peroxidase (POD) activity, catalase (CAT) activity and chlorophyll content (chlorophyll $a$, chlorophyll $b$ and total chlorophyll). The redundant supernatant was stored in 
a freezer at $-80^{\circ} \mathrm{C}$. All of the above relevant indicators were tested by corresponding kits, which were purchased from Nanjing Jiancheng Bioengineering Institute (http://www.njjcbio.com/) and the specific operation methods were consistent with the manufacturer's instructions.

\subsection{The Observation of Leaf Anatomy}

After two months of $C d$ stress treatment, fresh B. papyrifera leaves were selected and paraffin section technique [83] was used to observe changes in leaf anatomy. During the whole experimental operation, the cut leaves were fixed with FAA fixative which was prepared with $70 \%$ alcohol, glacial acetic acid and formalin. After $24 \mathrm{~h}$, the materials were dehydrated with alcohol from low to high concentration. The concentration and time were set to: $85 \%(1 \mathrm{~h}), 95 \%(1 \mathrm{~h}), 100 \%(1 \mathrm{~h})$ and $100 \%(1 \mathrm{~h})$. In order to enhance the refractive index of the tissue, the materials were cleared with xylene. The concentration ratio and time were set to: $1 / 2$ xylene $+1 / 2$ alcohol $(1 \mathrm{~h})$, xylene $(1 \mathrm{~h})$, xylene $(1 \mathrm{~h}), 1 / 2$ xylene + $1 / 2$ paraffin (30 $\mathrm{min}$, repeated three times). The materials were taken out and processed in the constant temperature incubator (model: 303-00, purchased from Guangzhou Kangheng Instrument Co., Ltd., Guangzhou, China) by low temperature waxing $\left(36^{\circ} \mathrm{C}, 1 \mathrm{~h}\right)$ and high temperature waxing $\left(55-60^{\circ} \mathrm{C}\right.$, $2 \mathrm{~h}$, repeated three times). After the materials had been immersed in wax for a sufficient period of time, it was necessary to embed the wax block, and then take it out after solidification and cut it into a suitable shape, and fix it onto a small wooden block with wax water. The wax tapes were cut to have a thickness of about $8 \mu \mathrm{m}$ using a KYD-QP biological tissue slice machine (Hubei Kangyida Medical Technology Co., Ltd., Xiaogan, China), were adhered to the glass slides, and placed on the KYD-TK biological tissue booth machine (Hubei Kangyida Medical Technology Co., Ltd.) at $30{ }^{\circ} \mathrm{C}$ to $35^{\circ} \mathrm{C}$. After the wax tapes were flattened and the water was completely evaporated, the slides could be saved in the slide box. Subsequently, in order to make different structures within the cell tissue present with different colors and strong enough differences for observation, we de-waxed the slides with xylene and alcohol, double stained them with $1 \%$ saffron $+0.5 \%$ fast green, and the slides were sealed with a neutral gum and observed under the electron microscope.

\subsection{Data Analysis}

Graph analysis were performed using SigmaPlot 12.5 software. The Kolmogorov-Smirnov Test was used to examine the normality of the data distribution. SPSS 20.0 software was used for two-way analyses of variance (ANOVA), the least significant difference (LSD) test was performed to assess the homogeneity of variance $(p>0.05)$, and the Games-Howell test was used to test significant difference $(p<0.05)$. All measurements were repeated three times and the data were expressed as mean values \pm standard error (SE).

\section{Conclusions}

In the research, we found that B. papyrifera adapts to damage caused by $\mathrm{Cd}$ stress via physiological and biochemical processes. B. papyrifera has a high biomass, even if $\mathrm{Cd}$ stress caused its root biomass to decrease significantly, and the MC of roots and stems were not affected by $\mathrm{Cd}$ stress. The roots of B. papyrifera could accumulate more heavy metals under high $\mathrm{Cd}$ concentrations, thus reducing the transfer to the aboveground part. The main detoxification mechanisms such as changes in the activities of antioxidant enzymes (SOD and POD) and the co-feedback of ROS played a major regulatory role. The increased protein of $B$. papyrifera seedlings and the developed root system constituted the primary barrier against external aggression. Cd could change the chlorophyll type and content of B. papyrifera leaves, and had a great influence on the synthesis of chloroplasts. In conclusion, our research has initially proved that $B$. papyrifera has the advantages of fast growth, a well-developed root system, strong soil and water conservation ability, and high biomass. B. papyrifera has strong enrichment ability under high $\mathrm{Cd}$ concentrations, making it suitable for being widely planted in heavy metal contaminated soil and used for soil and ecological environment restoration. 
Supplementary Materials: The following are available online at http://www.mdpi.com/2223-7747/9/12/1698/s1, Figure S1: Phenotypic characteristics of B. papyrifera seedling leaves under different Cd concentrations after $20 \mathrm{~d}$.

Author Contributions: Conceptualization, Z.X.; methodology, W.Z.; software, H.H.; validation, Y.Z., G.Y. and Z.X.; formal analysis, W.Z.; resources, J.Z.; data curation, W.Z.; writing-original draft preparation, W.Z.; writing-review and editing, Z.X.; visualization, G.Y.; supervision, Y.Z.; project administration, Z.X.; funding acquisition, Z.X., G.Y. and W.Z. All authors have read and agreed to the published version of the manuscript

Funding: The study was supported by National Natural Science Foundation of China (31700332); Major Science and Technology Program of Hunan Province (2017NK1014); Natural Science Foundation of Hunan Province (2019JJ50027); Technology R\&D Program of Changsha City (kq1901145); Key Projects of State Forestry and Grass Administration (201801); Key Technology R\&D Program of Hunan Province (2016TP2007, 2017TP2006); Scientific Innovation Fund for Post-graduates of Central South University of Forestry and Technology (CX20191004).

Acknowledgments: Thanks to the anonymous reviewers for their constructive comments. These comments helped us to improve the manuscript. Both of the reviewers pointed out that treatment concentration should be described as real Cd content $(\mathrm{mg} / \mathrm{kg})$, not irrigation concentration $(\mu \mathrm{mol} / \mathrm{L})$, for the pot experiment. All authors agreed that the changes might provide more reference to the actual project. This proposal not only improves our knowledge, but we are willing to emphasize it again to attract readers' attention.

Conflicts of Interest: The authors declare no conflict of interest.

\section{Abbreviations}

$\begin{array}{ll}\text { ABA } & \text { abscisic acid } \\ \text { BCF } & \text { bioconcentration factor } \\ \text { CAT } & \text { catalase } \\ \text { CBB } & \text { coomassie brilliant blue } \\ \text { DW } & \text { dry weight } \\ \text { FW } & \text { fresh weight } \\ \text { MDA } & \text { malondialdehyde } \\ \text { MC } & \text { moisture content } \\ \text { PTFE } & \text { polytetrafluoroethylene } \\ \text { POD } & \text { peroxidase } \\ \text { ROS } & \text { reactive oxygen species } \\ \text { SE } & \text { standard error } \\ \text { SOD } & \text { superoxide dismutase } \\ \text { TF } & \text { translocation factor } \\ \text { TBA } & \text { thiobarbituric acid }\end{array}$

\section{References}

1. Wang, X.; Sato, T.; Xing, B.; Tao, S. Health risks of heavy metals to the general public in Tianjin, China via consumption of vegetables and fish. Sci. Total Environ. 2005, 350, 28-37. [CrossRef]

2. Lee, Y.H.; Stuebing, R.B. Heavy metal contamination in the river toad, Bufo juxtasper (Inger), near a copper mine in East Malaysia. Bull. Environ. Contam. Toxicol. 1990, 45, 272-279. [CrossRef]

3. Vangronsveld, J.; Assche, F.V.; Clijsters, H. Reclamation of a bare industrial area contaminated by non-ferrous metals: In situ metal immobilization and revegetation. Environ. Pollut. 1995, 87, 51-59. [CrossRef]

4. Nriagu, J.O. A silent epidemic of environmental metal poisoning? Environ. Pollut. 1988, 50, 139-161. [CrossRef]

5. Douay, F.; Roussel, H.; Pruvot, C.; Loriette, A.; Fourrier, H. Assessment of a remediation technique using the replacement of contaminated soils in kitchen gardens nearby a former lead smelter in Northern France. Sci. Total Environ. 2008, 401, 29-38. [CrossRef]

6. Baczek-Kwinta, R.; Juzon, K.; Borek, M.; Antonkiewicz, J. Photosynthetic response of cabbage in cadmium-spiked soil. Photosynthetica 2019, 57, 731-739. [CrossRef]

7. Hernández-Allica, J.; Becerril, J.M.; Zárate, O.; Garbisu, C. Assessment of the efficiency of a metal phytoextraction process with biological indicators of soil health. Plant Soil 2006, 281, 147-158. [CrossRef]

8. Zhang, J.; Martinoia, E.; Lee, Y. Vacuolar transporters for cadmium and arsenic in plants and their applications in phytoremediation and crop development. Plant Cell Physiol. 2018, 59, 1317-1325. [CrossRef]

9. Antonkiewicz, J.; Kolodziej, B.; Bielinska, E.J.; Witkowicz, R.; Tabor, S. Using jerusalem artichoke to extract heavy metals from municipal sewage sludge amended soil. Pol. J. Environ. Stud. 2018, 27, 513-527. [CrossRef] 
10. Ma, L.Q. A fern that hyperaccumulates arsenic. World Environ. 2001, 409, 579. [CrossRef]

11. Chen, T.; Wei, C.; Huang, Z.; Huang, Q.; Lu, Q.; Fan, Z. Arsenic hyperaccumulator Pteris Vittata L. and its arsenic accumulation. Chin. Sci. Bull. 2002, 47, 902-905. [CrossRef]

12. Chen, T.; Lei, M.; Wan, X.; Yang, J.; Zhou, X. Arsenic hyperaccumulator Pteris vittata L. and its aplication to the field. In Twenty Years of Research and Development on Soil Pollution and Remediation in China; Springer: Singapore, 2018; pp. 465-476. [CrossRef]

13. Xue, S.; Chen, Y.; Lin, Q.; Xu, S.; Wang, Y. Phytolacca acinosa Roxb. (Phytolaccaceae): A new manganese hyperaccumulator plant from Southern China. Acta Ecol. Sin. 2003, 23, 935-937. [CrossRef]

14. Xue, S.; Chen, Y.; Luo, Y.; Reeves, R.D.; Lin, Q. Manganese tolerance and hyperaccumulation of Phytolacca acinosa Roxb. Acta Pedol. Sin. 2004, 41, 889-895. [CrossRef]

15. Liu, L.; Wu, L.; Li, N.; Luo, Y.; Li, S.; Li, Z.; Han, C.; Jiang, Y.; Christie, P. Rhizosphere concentrations of zinc and cadmium in a metal contaminated soil after repeated phytoextraction by Sedum plumbizincicola. Int. J. Phytoremediat. 2011, 13, 750-764. [CrossRef]

16. Liu, H.; Zhao, H.; Wu, L.; Liu, A.; Zhao, F.-J.; Xu, W. Heavy metal ATPase 3 (HMA3) confers cadmium hypertolerance on the cadmium/zinc hyperaccumulator Sedum plumbizincicola. New Phytol. 2017, 215, 687-698. [CrossRef] [PubMed]

17. Abid, M.; Zhang, Y.J.; Li, Z.; Bai, D.F.; Zhong, Y.P.; Fang, J.B. Effect of salt stress on growth, physiological and biochemical characters of four kiwifruit genotypes. Sci. Hortic. 2020, 271, 109473. [CrossRef]

18. Nikolić, N.; Zorić, L.; Cvetković, I.; Pajević, S.; Borišev, M.; Orlović, S.; Pilipović, A. Assessment of cadmium tolerance and phytoextraction ability in young Populus deltoides L. and Populus $\times$ euramericana plants through morpho-anatomical and physiological responses to growth in cadmium enriched soil. iForest Biogeosci. For. 2017, 10, 635-644. [CrossRef]

19. Zhou, J.; Jiang, Z.; Ma, J.; Yang, L.; Wei, Y. The effects of lead stress on photosynthetic function and chloroplast ultrastructure of Robinia pseudoacacia seedlings. Environ. Sci. Pollut. Res. 2017, 24, 10718-10726. [CrossRef]

20. Nóia Júnior, R.d.S.; Amaral, G.C.; Pezzopane, J.E.M.; Fonseca, M.D.S.; Câmara da Silva, A.P.; Xavier, T.M.T. Ecophysiological acclimatization to cyclic water stress in Eucalyptus. J. For. Res. 2019, 31, 797-806. [CrossRef]

21. Luo, y.y.; Wang, s.s.; Yan, j.; Tian, p. Effects of lead stress on anatomic structure of stems and leaves of Artemisia Sacrorum var. Messerschmidtiana. Bull. Soil Water Conserv. 2010, 30, 182-185. [CrossRef]

22. Huang, H.; Zhao, Y.; Xu, Z.; Zhang, W.; Jiang, K. Physiological responses of Broussonetia papyrifera to manganese stress, a candidate plant for phytoremediation. Ecotoxicol. Environ. Saf. 2019, 181, 18-25. [CrossRef] [PubMed]

23. Yang, L.P.; Zhu, J.; Wang, P.; Zeng, J.; Tan, R.; Yang, Y.Z.; Liu, Z.M. Effect of Cd on growth, physiological response, Cd subcellular distribution and chemical forms of Koelreuteria paniculata. Ecotoxicol. Environ. Saf. 2018, 160, 10-18. [CrossRef] [PubMed]

24. Sitko, K.; Rusinowski, S.; Kalaji, H.M.; Szopinski, M.; Malkowski, E. Photosynthetic Efficiency as Bioindicator of Environmental Pressure in A. halleri. Plant Physiol. 2017, 175, 290-302. [CrossRef] [PubMed]

25. Moradi, L.; Ehsanzadeh, P. Effects of Cd on photosynthesis and growth of safflower (Carthamus tinctorius L.) genotypes. Photosynthetica 2015, 53, 506-518. [CrossRef]

26. González-Lorca, J.; Rivera-Hutinel, A.; Moncada, X.; Lobos, S.; Seelenfreund, D.; Seelenfreund, A. Ancient and modern introduction of Broussonetia papyrifera ([L.] Vent.; Moraceae) into the Pacific: Genetic, geographical and historical evidence. N. Z. J. Bot. 2015, 53, 75-89. [CrossRef]

27. Peñailillo, J.; Olivares, G.; Moncada, X.; Payacán, C.; Chang, C.S.; Chung, K.F.; Matthews, P.J.; Seelenfreund, A.; Seelenfreund, D. Sex distribution of paper mulberry (Broussonetia papyrifera) in the Pacific. PLoS ONE 2016, 11, e0161148. [CrossRef]

28. Zhang, X.; Qu, L.J.; Guo, X.Q. Study on structure and property of Broussonetia papyrifera (BP) fiber. Adv. Mater. Res. 2011, 146-147, 1593-1596. [CrossRef]

29. Zhang, Z.; Zhang, Y.; Yu, C.; Yu, H. Research of degumming process, microstructure and properties of mulberry fiber. J. Donghua Univ. (Engl. Ed.) 2007, 24, 170-172.

30. Moncada, X.; Payacán, C.; Arriaza, F.; Lobos, S.; Seelenfreund, D.; Seelenfreund, A. DNA extraction and amplification from contemporary polynesian bark-cloth. PLoS ONE 2013, 8, e56549. [CrossRef]

31. Teodoro, P.E.; Peña-Ahumada, B.; Saldarriaga-Córdoba, M.; Kardailsky, O.; Moncada, X.; Moraga, M.; Matisoo-Smith, E.; Seelenfreund, D.; Seelenfreund, A. A tale of textiles: Genetic characterization of historical paper mulberry barkcloth from Oceania. PLoS ONE 2020, 15, e0233113. [CrossRef] 
32. Daud, M.; Khalid, N.; Iqbal, J.; Ahmad, S.; Zaidi, J.H. Potential of Broussonetia papyrifera leaves as biomonitors for atmospheric pollution: Use of INAA and AAS techniques. Radiochim. Acta 2006, 94, 871-877. [CrossRef]

33. Sun, J.; Zhang, C.S.; Yu, L.N.; Bi, J.; Liu, S.F.; Zhu, F.; Yang, Q.L. Chemical composition of Broussonetia Papyrifera flowers. Adv. Mater. Res. 2011, 236-238, 2581-2585. [CrossRef]

34. Sun, J.; Zhang, C.S.; Yu, L.N.; Bi, J.; Liu, S.F.; Zhu, F.; Yang, Q.L. Antioxidant activity and total phenolics of Broussonetia papyrifera flower extracts. Appl. Mech. Mater. 2012, 140, 263-267. [CrossRef]

35. Pang, S.; Wang, G.; Lin, J.; Diao, Y.; Xu, R. Cytotoxic activity of the alkaloids from Broussonetia papyrifera fruits. Pharm. Biol. 2014, 52, 1315-1319. [CrossRef]

36. Xu, M.L.; Wang, L.; Hu, J.H.; Lee, S.K.; Wang, M.H. Antioxidant activities and related polyphenolic constituents of the methanol extract fractions from Broussonetia papyrifera stem bark and wood. Food Sci. Biotechnol. 2010, 19, 677-682. [CrossRef]

37. Wu, W.T. Evaluation of anti-inflammatory effects of Broussonetia papyrifera stem bark. Indian J. Pharmacol. 2012, 44, 26-30. [CrossRef]

38. Wu, L.; Xu, Z.; Zhang, W.; Ding, Y.; Tang, Y.; Zhao, Y. Potential distribution of Broussonetia papyrifera in China based on MaxEnt model. J. Central South Univ. For. Technol. 2018, 38, 40-45. [CrossRef]

39. Saito, K.; Linquist, B.; Keobualapha, B.; Shiraiwa, T.; Horie, T. Broussonetia papyrifera (paper mulberry): Its growth, yield and potential as a fallow crop in slash-and-burn upland rice system of northern Laos. Agrofor. Syst. 2009, 76, 525-532. [CrossRef]

40. Li, M.; Li, Y.; Li, H.; Wu, G. Overexpression of AtNHX5 improves tolerance to both salt and drought stress in Broussonetia papyrifera (L.) Vent. Tree Physiol. 2011, 31, 349-357. [CrossRef]

41. Zhang, M.; Fang, Y.; Ji, Y.; Jiang, Z.; Wang, L. Effects of salt stress on ion content, antioxidant enzymes and protein profile in different tissues of Broussonetia papyrifera. S. Afr. J. Bot. 2013, 85, 1-9. [CrossRef]

42. Sun, J.; Peng, X.; Fan, W.; Tang, M.; Liu, J.; Shen, S. Functional analysis of BpDREB2 gene involved in salt and drought response from a woody plant Broussonetia papyrifera. Gene 2014, 535, 140-149. [CrossRef] [PubMed]

43. Zhao, X.; Liu, J.; Xia, X.; Chu, J.; Wei, Y.; Shi, S.; Chang, E.; Yin, W.; Jiang, Z. The evaluation of heavy metal accumulation and application of a comprehensive bio-concentration index for woody species on contaminated sites in Hunan, China. Environ. Sci. Pollut. Res. 2014, 21, 5076-5085. [CrossRef] [PubMed]

44. Hall, J.L. Cellular mechanisms for heavy metal detoxification and tolerance. J. Exp. Bot. 2002, 53, 1-11. [CrossRef] [PubMed]

45. Vos, C.H.R.D.; Schat, H.; Waal, M.A.M.D.; Vooijs, R.; Ernst, W.H.O. Increased resistance to copper-induced damage of the root cell plasmalemma in copper tolerant Silene cucubalus. Physiol. Plant. 1991, 82, 523-528. [CrossRef]

46. Petrov, V.D.; Van Breusegem, F. Hydrogen peroxide-a central hub for information flow in plant cells. AoB Plants 2012, 2012, pls014. [CrossRef]

47. Kurusu, T.; Kuchitsu, K.; Tada, Y. Plant signaling networks involving Ca(2+) and Rboh/Nox-mediated ROS production under salinity stress. Front. Plant Sci. 2015, 6, 427. [CrossRef]

48. Dietz, K.J.; Baier, M.; Krämer, K. Free Radicals and Reactive Oxygen Species as Mediators of Heavy Metal Toxicity in Plants; Springer: Berlin/Heidelberg, Germany, 1999; pp. 73-97.

49. Assche, F.; Clijsters, H. Effects of metals on enzyme activity in plants. Plant Cell Environ. 1990, 13, 195-206. [CrossRef]

50. Halliwell, B. Reactive species and antioxidants. Redox biology is a fundamental theme of aerobic life. Plant Physiol. 2006, 141, 312-322. [CrossRef]

51. Cheng, H.; Liu, Q.; Ma, M.; Liu, Y.; Wang, W.; Ning, W. Cadmium tolerance, distribution, and accumulation in Taraxacum ohwianum Kitam. as a potential Cd-hyperaccumulator. Int. J. Phytoremed. 2019, 21, 541-549. [CrossRef]

52. Hu, P.-J.; Gan, Y.-Y.; Tang, Y.-T.; Zhang, Q.-F.; Jiang, D.; Yao, N.; Qiu, R.-L. Cellular tolerance, accumulation and distribution of cadmium in leaves of hyperaccumulator Picris divaricata. Pedosphere 2012, 22, 497-507. [CrossRef]

53. Qiu, Q.; Wang, Y.; Yang, Z.; Yuan, J. Effects of phosphorus supplied in soil on subcellular distribution and chemical forms of cadmium in two Chinese flowering cabbage (Brassica parachinensis L.) cultivars differing in cadmium accumulation. Food Chem. Toxicol. 2011, 49, 2260-2267. [CrossRef] [PubMed]

54. Aibibu, N.; Liu, Y.; Zeng, G.; Wang, X.; Chen, B.; Song, H.; Xu, L. Cadmium accumulation in Vetiveria zizanioides and its effects on growth, physiological and biochemical characters. Bioresour. Technol. 2010, 101, 6297-6303. [CrossRef] [PubMed] 
55. Gadallah, M.A.A. Effects of indole-3-acetic acid and zinc on the growth, osmotic potential and soluble carbon and nitrogen components of soybean plants growing under water deficit. J. Arid Environ. 2000, 44, 451-467. [CrossRef]

56. Reinheckel, T.; Noack, H.; Lorenz, S.; Wiswedel, I.; Augustin, W. Comparison of protein oxidation and aldehyde formation during oxidative stress in isolated mitochondria. Free Radic. Res. Commun. 1998, 29, 297-305. [CrossRef] [PubMed]

57. Chaoui, A.; Mazhoudi, S.; Ghorbal, M.H.; Ferjani, E.E. Cadmium and zinc induction of lipid peroxidation and effects on antioxidant enzyme activities in bean (Phaseolus vulgaris L.). Plant Sci. 1997, 127, 139-147. [CrossRef]

58. Li, Y.; Zhang, S.; Jiang, W.; Liu, D. Cadmium accumulation, activities of antioxidant enzymes, and malondialdehyde (MDA) content in Pistia stratiotes L. Environ. Sci. Pollut. Res. 2013, 20, 1117-1123. [CrossRef]

59. Ge, W.; Jiao, Y.; Jiang, W.; Liu, D. Ultrastructural and photosynthetic response of Populus 107 leaves to cadmium stress. Pol. J. Environ. Stud. 2015, 24, 519-527. [CrossRef]

60. Van den Ende, W.; Valluru, R. Sucrose, sucrosyl oligosaccharides, and oxidative stress: Scavenging and salvaging? J. Exp. Bot. 2009, 60, 9-18. [CrossRef]

61. Ma, Y.Y.; Zhang, Y.; Jiang, L.; Shao, H.B. Roles of plant soluble sugars and their responses to plant cold stress. Afr. J. Biotechnol. 2009, 8, 2004-2010. [CrossRef]

62. Shao, X.; Zhu, Y.; Cao, S.; Wang, H.; Song, Y. Soluble sugar content and metabolism as related to the heat-induced chilling tolerance of loquat fruit during cold storage. Food Bioprocess Technol. 2012, 6, 3490-3498. [CrossRef]

63. Couee, I.; Sulmon, C.; Gouesbet, G.; El Amrani, A. Involvement of soluble sugars in reactive oxygen species balance and responses to oxidative stress in plants. J. Exp. Bot. 2006, 57, 449-459. [CrossRef] [PubMed]

64. Szabados, L.; Savouré, A. Proline: A multifunctional amino acid. Trends Plant Sci. 2010, 15, 89-97. [CrossRef] [PubMed]

65. Srinivas, V.; Balasubramanian, D. Proline is a protein-compatible hydrotrope. Langmuir 1995, 11, 2830-2833. [CrossRef]

66. Huang, G.Y.; Wang, Y.S. Physiological and biochemical responses in the leaves of two mangrove plant seedlings (Kandelia candel and Bruguiera gymnorrhiza) exposed to multiple heavy metals. J. Hazard. Mater. 2010, 182, 848-854. [CrossRef] [PubMed]

67. Mehta, S.K.; Gaur, J.P. Heavy-metal-induced proline accumulation and its role in ameliorating metal toxicity in Chlorella vulgaris. New Phytol. 2010, 143, 253-259. [CrossRef]

68. Schat, H.; Sharma, S.S.; Vooijs, R. Heavy metal-induced accumulation of free proline in a metal-tolerant and a nontolerant ecotype of Silene vulgaris. Physiol. Plant. 1997, 101, 477-482. [CrossRef]

69. Chen, C.T.; Chen, L.M.; Lin, C.C.; Kao, C.H. Regulation of proline accumulation in detached rice leaves exposed to excess copper. Plant Sci. 2001, 160, 283-290. [CrossRef]

70. Sharma, S.S.; Dietz, K.J. The significance of amino acids and amino acid-derived molecules in plant responses and adaptation to heavy metal stress. J. Exp. Bot. 2006, 57, 711-726. [CrossRef]

71. Slooten, L.; Capiau, K.; Camp, W.V.; Montagu, M.V.; Sybesma, C.D. Factors affecting the enhancement of oxidative stress tolerance in transgenic tobacco overexpressing manganese superoxide dismutase in the chloroplasts. Plant Physiol. 1995, 107, 737-750. [CrossRef]

72. Dazy, M.; Masfaraud, J.F.; Ferard, J.F. Induction of oxidative stress biomarkers associated with heavy metal stress in Fontinalis antipyretica Hedw. Chemosphere 2009, 75, 297-302. [CrossRef]

73. Qureshi, M.I.; Abdin, M.Z.; Qadir, S.; Iqbal, M. Lead-induced oxidative stress and metabolic alterations in Cassia angustifolia Vahl. Biol. Plant. 2007, 51, 121-128. [CrossRef]

74. Mobin, M.; Khan, N.A. Photosynthetic activity, pigment composition and antioxidative response of two mustard (Brassica juncea) cultivars differing in photosynthetic capacity subjected to cadmium stress. J. Plant Physiol. 2007, 164, 601-610. [CrossRef] [PubMed]

75. Liu, Y.; Wang, X.; Zeng, G.; Qu, D.; Gu, J.; Zhou, M.; Chai, L. Cadmium-induced oxidative stress and response of the ascorbate-glutathione cycle in Bechmeria nivea (L.) Gaud. Chemosphere 2007, 69, 99-107. [CrossRef] [PubMed]

76. Huang, Q.C.; Wei, Y.H. Comparative analysis of chlorophyll content on several sun plants and shade Plants. Hubei Agric. Sci. 2009, 48, 1923-1924. [CrossRef]

77. Zhi, Y.; Zhou, Q.; Leng, X.; Zhao, C. Mechanism of remediation of cadmium-contaminated soil with low-energy plant Snapdragon. Front. Chem. 2020, 8, 222. [CrossRef] [PubMed] 
78. Jin, C.; Nan, Z.; Wang, H.; Li, X.; Zhou, J.; Yao, X.; Jin, P. Effect of Cd stress on the bioavailability of Cd and other mineral nutrition elements in broad bean grown in a loess subsoil amended with municipal sludge compost. Environ. Sci. Pollut. Res. 2017, 25, 7418-7432. [CrossRef] [PubMed]

79. Li, X.; Yang, Y. Preliminary study on Cd accumulation characteristics in Sansevieria trifasciata Prain. Plant Divers. 2020, 42, 351-355. [CrossRef]

80. Dou, X.; Dai, H.; Skuza, L.; Wei, S. Bidens pilosa L. hyperaccumulating Cd with different species in soil and the role of EDTA on the hyperaccumulation. Environ. Sci. Pollut. Res. Int. 2019, 26, 25668-25675. [CrossRef]

81. Toth, G.; Hermann, T.; Da Silva, M.R.; Montanarella, L. Heavy metals in agricultural soils of the European Union with implications for food safety. Environ. Int. 2016, 88, 299-309. [CrossRef]

82. Adagunodo, T.A.; Sunmonu, L.A.; Emetere, M.E. Heavy metals' data in soils for agricultural activities. Data Brief 2018, 18, 1847-1855. [CrossRef]

83. Hou, C.; Xu, S. Analysis on the key influence factors of paraffin section's quality. Chin. Agric. Sci. Bull. 2009, 25, 94-98.

Publisher's Note: MDPI stays neutral with regard to jurisdictional claims in published maps and institutional affiliations.

(C) 2020 by the authors. Licensee MDPI, Basel, Switzerland. This article is an open access article distributed under the terms and conditions of the Creative Commons Attribution (CC BY) license (http://creativecommons.org/licenses/by/4.0/). 